\title{
Plan for the Sustainability of Public Buildings through the Energy Efficiency Certification System: Case Study of Public Sports Facilities, Korea
}

\author{
Seon Gyeong Baek
}

check for

updates

Citation: Baek, S.G. Plan for the Sustainability of Public Buildings through the Energy Efficiency

Certification System: Case Study of Public Sports Facilities, Korea. Buildings 2021, 11, 589. https:// doi.org/10.3390/buildings11120589

Academic Editors: Chyi Lin Lee, Samad M. E. Sepasgozar and Lan Ding

Received: 4 October 2021

Accepted: 24 November 2021

Published: 26 November 2021

Publisher's Note: MDPI stays neutral with regard to jurisdictional claims in published maps and institutional affiliations.

Copyright: (C) 2021 by the author. Licensee MDPI, Basel, Switzerland. This article is an open access article distributed under the terms and conditions of the Creative Commons Attribution (CC BY) license (https:/ / creativecommons.org/licenses/by/ $4.0 /)$.
Architecture \& Urban Research Institute, Sejong-si 30116, Korea; sgbaek@auri.re.kr; Tel.: +82-44-417-9605

\begin{abstract}
This study examines strategies for energy efficiency in public buildings in Korea and the implementation of certification systems. It also identifies the actual plan status and discusses improvements at the institutional level. The target is the national sports centers, where the discussion on energy efficiency has been assiduous, as they have recently expanded regionally in Korea. Among the 541 national sports centers in Korea, 90 facilities for which a preliminary review was performed on the plan by the National Public Building Center were analyzed. The energy efficiency plan is realized through Building Energy Efficiency, Zero Energy Building, and Green Standard for Energy and Environmental Design certifications. As a result of analyzing the plan status, omissions or errors in certification were confirmed in about $10 \%$ of each, even though more than $80 \%$ of the facilities were subject to mandatory application. In Korea's condition, to revitalize the practice of the system, it is necessary to expand the government's publicity and support initiatives, use differential application of evaluation items, and strengthen incentives. This study provides meaningful results and suggestions for implementing an energy efficiency system at the national level under similar conditions in the future.
\end{abstract}

Keywords: public building; public sports facility; energy efficiency certification; Building Energy Efficiency; Zero Energy Building; Green Standard for Energy and Environmental Design

\section{Introduction}

Energy efficiency of buildings is an important issue with regard to sustainable development goals (SDGs). Buildings are one of the most energy-consuming objects, and continue to increase. According to the 2018 Global Status Report of the International Energy Agency (IEA), buildings account for the highest percentage of final energy use worldwide, at approximately $35 \%$. In terms of $\mathrm{CO}_{2}$ emissions, the buildings and buildings construction sectors together account for nearly $40 \%$ [1]. Energy use in buildings has slowed down since 2010 , but it is still on the rise; and if there is no action to reduce it, it is expected to exceed $50 \%$ by 2050 [2].

Accordingly, in some European countries and the United States, the effectiveness of sustainable building development is being improved and energy savings are already being derived by categorizing the systems in detail [3]. Some countries in Europe and Asia that urgently need energy efficiency implementation are working hard to establish and operate the system [4,5]. In Korea, as of 2018, 84\% of the total primary energy supply among IEA member countries depended on imports, and the proportion of renewable energy was the lowest. To overcome this problem, the Korean government announced the 2020 Green New Deal policy and mentioned that related systems should be more actively implemented to reduce carbon emissions [6]. In particular, since reducing greenhouse gas emissions and reducing heating energy consumption were presented as major items, a direction was set to strengthen mandatory regulations based on the existing law in relation to buildings. In countries such as the United States and the United Kingdom, various energy-efficiency-related systems have been established through gradual social 
consensus on sustainability, whereas in Korea, the government's system was preceded by necessity [7]. Under these conditions, Korea is now standing at a point where it is necessary to further spread awareness of the need for energy efficiency for sustainability and increase its execution capacity.

In Korea, institutional devices for building energy efficiency have been established as follows. Regarding sustainability, Korea enacted the Sustainable Development Act (SDA) in 2007. Through this law, sustainability was defined as achieving harmony and balance in the present without wasting economic, social, and environmental resources or degrading the conditions for future generations [8]. In particular, SDA raised awareness regarding sustainability in Korea by providing the basis for the role of the state and local governments in sustainability and related research, education, and publicity [9]. In 2010, the Framework Act on Low Carbon, Green Growth, was enacted in connection with the concept of sustainability stipulated by the SDA. For sustainability, a national implementation direction for low-carbon-based green growth was established, and detailed principles were stipulated accordingly. In Korea, in particular, as the brown industry was predominant, both industrial restructuring and green development strategies were needed for each sector [10].

Meanwhile, as the international demand for energy efficiency in buildings increased, the Korean government enacted the Green Buildings Construction Support Act (GBA) for low-carbon buildings in 2012. In GBA, sustainable buildings that minimize the impact on buildings and the environment while providing a pleasant and healthy living environment are designated as "green buildings". It also stipulates the mandatory requirements for buildings constructed by private or public institutions. In particular, around the world, green buildings reduce the cost of maintenance and end life by approximately $10-30 \%$; however, construction costs are much higher [11,12]. Therefore, the Korean government, which needs to encourage project implementers to construct buildings in accordance with mandatory regulations, provides administrative and financial support for the construction related to energy efficiency [13].

In particular, in the 2000s, the sustainability of public architecture became an important issue in Korea. In Korea, where modernization and industrialization took place through the Japanese colonial period in the early 1900s, the central government built a large amount of public architecture rapidly after the 1960s [14]. The results became evident in the 2000s, and various discussions and practices were used to decide on design, distribution, and construction methods [15]. Above all, as public buildings are built in a short time from the point of view of supply, these buildings are quite outdated and have problems such as asbestos, even though only about 20-30 years have passed. As a result, new construction or renovation becomes inevitable. These issues are closely related not only to a country's budget or workforce issues, but also to global environmental issues. The Korean government has announced a plan to reduce greenhouse gas emissions by $37 \%$ by 2030 compared to 2020 and to be carbon neutral by 2050, and concrete implementation for this is an important point [16]. Accordingly, the government regulates public institutions to obtain essential certifications when constructing or remodeling buildings and provides incentives and expands the scope of each.

However, when a business department promotes a public project, in many cases, they do not properly understand energy efficiency and review appropriate certification [17]. This is because the pilot projects for each certification have just been completed, the regulations are constantly being revised and supplemented, and the obligations or recommendations to be applied differ depending on the characteristics of the facility [18]. Accordingly, it is time to clarify the energy efficiency strategy based on the current plan for each type and discuss the method for active implementation.

This study confirms the energy efficiency plan strategy by focusing on public sports facilities that have recently expanded nationally. Studies on the direction and methods of energy efficiency systems in terms of public policy have been conducted worldwide. Depending on the characteristics of each country, there have been discussions about long- 
term frameworks [19] or public awareness and participation [20,21]. In the building sector, research on related technologies and certifications continues, regardless of the country. In particular, in Asian countries including Korea, research on energy consumption, application of new technologies, and related certification systems have been mainly conducted rather than verifying the effects and results [22,23].

In Korea, with respect to energy efficiency certification applied to public buildings, research has been mainly conducted on the application method for each certification over the past 10 years $[24,25]$. Above all, there have been many cases of reviewing related systems while checking the ratio of energy consumption to the entire public building [7]. In addition, it has been discussed how the certification plan for a specific type appears centered on public offices and apartments $[26,27]$; however, no study has comprehensively analyzed the status of the related certification system and plans for the recently expanding public sports facilities.

Public sports facilities in Korea rank 7th among the 10 types of facilities in terms of total floor area among public architectures in Korea [18] (p. 9). In particular, public sports facilities, such as a national sports center, which will be built as a living-friendly facility by 2027 , are on the rise according to the current national policy. Since sports facilities use a large amount of energy by operating swimming pools and gyms, from 2020, the Ministry of Culture, Sports, and Tourism added support for the construction of energy-efficient buildings for the sustainability of facilities. This study comprehensively identifies the energy efficiency certification system for the sustainability of such public buildings and analyzes the energy efficiency planning status. In addition, it suggests measures that need to be added or improved at the institutional level to activate the certification plan.

\section{Materials and Methods}

In Section 2, among public buildings, public sports facilities, which are the subject of this study, and related energy efficiency certifications are discussed, and the analysis method and process are explained.

In Korea, sports facilities are classified into private and public sports facilities according to the Act on the Installation and Use of Sports Facilities, and public sports facilities refer to types created and operated by the state and local governments. In connection with the Seoul Olympic Games held in Korea in 1988, public sports facilities began to be built in each region as a result of the revitalization policy of living sports [28] (p. 3). Particularly, under the name of the National Sports Center, living sports facilities based on swimming pools and gymnasiums have been built in 226 local governments across the country with support from the National Sports Promotion Fund (NSPF). From 1997 to 2020, 541 buildings were built with government support [29]. In other words, there are about one or two in each region in Korea, which is only 1 per 140,000 people in terms of supply standards. This is quite different from that of neighboring countries, such as Japan, where it is 1 per 290,000 people and Norway, where it is 1 per 5000 [28] (p. 4). Although a public sports facility is a base facility in the region, it is not a facility closely related to daily life. Accordingly, the government is promoting and implementing full-scale expansion with the goal of approximately 161 additional facilities by 2027 (Table 1). In particular, in relation to the aforementioned Green New Deal policy to reduce energy consumption in the country, to actively apply the relevant system in the supply of sports facilities, support for major certifications is being expanded. When planning a zero-energy facility, if an application is made to the Ministry of Culture, Sports, and Tourism, the government provides about 840,000 USD per facility to install solar panels and geothermal energy [30]. 
Table 1. Types and characteristics of a national sports center.

\begin{tabular}{|c|c|c|}
\hline Division & Type1: Base-Type Facility & Type2: Life-Friendly-Type Facility \\
\hline Definition & Local base public sports facilities & Living area public sports facilities \\
\hline Standard & $\begin{array}{l}1 \text { per each local government (population over } \\
500,000 \text { can be added) }\end{array}$ & Sports facilities blind spot \\
\hline Procedure & $\begin{array}{c}\text { Local government application (limited to once) } \rightarrow \\
\mathrm{KSPO}^{1} \text { review and support confirmation } \\
\rightarrow \text { Facility creation }\end{array}$ & $\begin{array}{l}\text { Local government application } \\
\rightarrow \mathrm{KSPO}^{1} \text { review and support confirmation } \\
\rightarrow \text { Facility creation }\end{array}$ \\
\hline $\mathrm{NSPF}^{2}$ & 2.3 2.7 million USD & 2.5 3.4 million USD \\
\hline Detail type & $\begin{array}{l}\text { Classified by program } \\
\text {-Basic swimming pool type, multi-purpose gym type, } \\
\text { gym complex type }\end{array}$ & $\begin{array}{l}\text { Classification according to regional } \\
\text { characteristics } \\
\text {-City growth type, small-town growth type, } \\
\text { city-specific type, a small-town specific type }\end{array}$ \\
\hline Program & Sports-oriented program operation & $\begin{array}{c}\text { Operation of programs that include local and } \\
\text { community activities }\end{array}$ \\
\hline
\end{tabular}

${ }^{1}$ Korea Sports Promotion Foundation; ${ }^{2}$ National Sports Promotion Fund.

In Korea, according to the public building construction procedure, when each business department completes a project plan, including a plan for energy efficiency, an architect is selected after the preliminary review and public building deliberation. In other words, the energy efficiency certification plan is confirmed in the preliminary review process, and its adequacy is evaluated in public building deliberation. This procedure for creating public buildings is applied in accordance with the Act on the Promotion of the Building Service Industry. A preliminary review is mandatory when the estimated design cost is approximately 85,000 USD or more, and this review has been conducted by the National Public Building Center (NPBC) since 2014 [31]. As a result of checking the standards and data reviewed by NPBC, the mandatory energy efficiency systems applied to the creation or remodeling of public sports facilities are Building Energy Efficiency Grade (BEE), Zero Energy Building (ZEB), and Green Standard for Energy and Environmental Design (G-SEED) certifications.

Internationally, the sustainability of buildings, above all else, is realized through the development of evaluation tools for eco-friendly buildings. As mentioned above, many indicators used in Europe and the United States are referenced, and standards differ depending on the characteristics of countries [32]. Specifically, considering sustainability, there was a discussion about applying detailed items, with an appropriate weight, based on the characteristics of each country [33]. The creation of sustainable buildings in Korea is promoted by five principles according to the GBA. As mentioned earlier, Korea's main objective is to minimize greenhouse gas emissions from the environment. The first is to create a building by reducing greenhouse gas emissions. The second is to create an environment-friendly and sustainable building. The third is to create a building that uses new and renewable energy and saves resources. The fourth is to improve the energy efficiency of existing buildings, and the fifth is to secure a balance between the different areas of these buildings [8]. Based on these principles, a certification system related to the energy efficiency of public buildings was prepared and classified. In previous studies, energy-related evaluation tools for buildings were compared using five dimensions of sustainability: environmental, social, economic, cultural, and governance [33]. The Korean certifications, however, focus mainly on energy resources and material, along with resource consumption and environmental waste [23]. These are being evaluated based on embodied primary energy use. In addition, the final cost reduction is mainly considered from the economic perspective [34]. However, the consideration of user convenience in the social aspect has neither been proven through the system in a quantitative dimension [13], nor in a cultural dimension. In terms of governance, the longer-term life cycle management of a building is unclear. 
The BEE certification is a rating system that promotes growth of buildings with high energy performance and spreads awareness about effective building energy management by providing quantitative and objective information on building energy performance [35]. Calculating and grading buildings' energy consumption has been practiced in many countries before, but there are differences in the standards and scope of mandatory application [36].

ZEB stipulates its definition in GBA and refers to a green building that minimizes the energy load required by the building and minimizes the energy consumption by using new and renewable energy. Therefore, it is closely related to the BEE grade, because the calculation of the energy requirement must be performed. In Korea, ZEB was systematically started in 2014. At that time, the government established a basic plan for green buildings and announced a plan to activate ZEB; after a pilot project, the certification system started in 2017. From 2020, the scope of mandatory targets for public buildings has been stipulated. The government specified and announced the implementation of this mandatory ZEB by amending the GBA, and it is expected to reduce energy import costs by approximately 1 billion USD per year by 2030 [6,37].

ZEB has been realized in the United States, Europe, and Japan, and its definition varies depending on the detailed regulations of each country. In Europe, ZEB is a building with high energy performance architecturally and equipmentally for heating, cooling, hot water supply, lighting, and ventilation, and includes renewable energy produced at the site or nearby areas. In the United States, it is a building in which the energy used per year and the energy produced are the same; similarly, in Japan, ZEB is defined as a building in which the total annual energy consumption is zero [38-41]. Although ZEB is a simple concept, there is no internationally agreed definition [42]. While many studies have been conducted, the detailed differences are still under discussion; in particular, there should be a common agreement on the category of zero and the definition of energy-efficient building. In addition, there is generally a need to clarify the scope of applied technologies that can be supplied $[43,44]$. These points are closely related to the life-cycle energy evaluation for zero energy. In the case of Korea, it is not yet at the stage of identifying and applying detailed variables for each type in relation to life cycle evaluation. In the international discussion, there are significant differences depending on the type and size of the facilities [45]. In the case of sports facilities, space efficiency is important not only because of materials, heating, and circulation, but also because many users use them all the time [46,47].

G-SEED is a system that grants eco-friendly building certification to buildings that have contributed to energy saving and environmental pollution reduction in the entire process, including the design, construction, and management of buildings, in accordance with the rules for green building certification of the Ministry of Environment and GBA. In 2002, the government started an eco-friendly building certification system for apartment houses. In 2005, related laws were established, and in 2008, the certification rules and standards were revised. Thereafter, as the GBA was enacted in 2013, the scope gradually expanded.

This study analyzes the current status of the energy efficiency plan in these three aspects, based on the plan data of the national sports center, a public sports facility for living, reviewed by NPBC. The NPBC data include business planning and architectural planning related to the three certifications. For comparison of plans, of 541 national sports centers created in Korea by 2020, the disabled and small gym types were excluded. As a result of checking the projects that performed preliminary reviews through NPBC among 354 projects, 90 were found. After classifying 90 projects by detailed facility type, plan data were extracted to derive the current status and characteristics. Based on this, the study discusses ways to improve and enhance the implementation of an energy efficiency certification plan (Table 2). 
Table 2. Research flow and method.

\begin{tabular}{|c|c|c|c|}
\hline Step & & Contents & \\
\hline \multirow[b]{2}{*}{ Step 1} & $\begin{array}{l}\text { Confirmation of energy efficiency } \\
\text { certification system related to } \\
\text { public sports facilities in Korea }\end{array}$ & $\begin{array}{l}\text { BEE, ZEB, G-SEED } \\
\text { Definition, scope, application target, } \\
\text { characteristics by certification system }\end{array}$ & Literature analysis \\
\hline & $\begin{array}{l}\mathrm{NPBC}^{1} \text { 's data verification and } \\
\text { related items derivation }\end{array}$ & $\begin{array}{l}\text { Projects for which planning was reviewed } \\
\text { through NPBC among all } 354 \text { facilities } \\
\text { Business plan and architectural plan related } \\
\text { to the certification plan for each project }\end{array}$ & $\begin{array}{c}90 \text { public sports facilities } \\
\text { data check }\end{array}$ \\
\hline \multirow{3}{*}{ Step 2} & Classification of detailed types & Base-type & $\begin{array}{l}29 \text { facility certification } \\
\text { plan status analysis }\end{array}$ \\
\hline & & Life-friendly-type & $\begin{array}{l}61 \text { facility certification } \\
\text { plan status analysis }\end{array}$ \\
\hline & \multicolumn{3}{|c|}{ Deduction of the status and characteristics of certification plans by type } \\
\hline Step 3 & \multicolumn{3}{|c|}{ Proposal of additional and improvement needs at the institutional level to revitalize the energy efficiency plan } \\
\hline
\end{tabular}

\section{Results}

Section 3 explains the results of analyzing the energy efficiency plan status for a total of 90 projects for which a preliminary review was performed through the NPBC.

- $\quad$ Building Energy Efficiency Grade (BEE) Certification

BEE determines the grade by measuring the total primary energy consumption per unit area by calculating the energy requirements for heating, cooling, hot water supply, lighting, and ventilation, dividing them by the floor area of each space and adding them up. The certification level is divided into $1+++, 1++, 1+$, and $1-7$ grades (total of 10 grades) according to the required amount. Buildings other than residential buildings are determined according to the annual primary energy consumption per unit area (less than 80 to less than $700 \mathrm{kWh} / \mathrm{m}^{2}$ ). (1) It is divided into $1+++$ grade when it is less than $80,1++$ grade when 80 or more but less than 140,1+ grade when 140 or more but less than 200, 1 grade when 200 or more but less than 260, and 2 grade when 260 or more but less than 320 .

Primary energy consumption $\left(\mathrm{kWh} / \mathrm{m}^{2} \cdot\right.$ year $)=\sum$ Energy consumption by use $\times$ Primary energy conversion factor

According to the GBA and Energy Use Rationalization Act, BEE is mandatory for public buildings with a total floor area of $3000 \mathrm{~m}^{2}$ or more that are newly built or expanded by public institutions or market-type and quasi-market-type public enterprises. The same applies to apartments created by public institutions. (Table 3)

Table 3. Targets and grades for building energy efficiency ratings for public buildings.

\begin{tabular}{|c|c|c|c|c|}
\hline Division & Size and Type & $\begin{array}{l}\text { Project Ordering } \\
\text { Organization }\end{array}$ & Grade & $\begin{array}{l}\text { Primary Energy } \\
\text { Consumption } \\
\left(\mathrm{kWh} / \mathrm{m}^{2} \cdot \text { year }\right)\end{array}$ \\
\hline \multirow{3}{*}{ BEE } & \multirow{2}{*}{$\begin{array}{l}\text { New construction or extension of } \\
\text { a separate building with a total } \\
\text { floor area of } 3000 \mathrm{~m}^{2} \text { or more }\end{array}$} & Public institutions & Grade 1 or higher & $\begin{array}{l}\text { Grade 1: } 80 \text { or more } \\
\text { and less than } 140\end{array}$ \\
\hline & & $\begin{array}{c}\text { Market-type, } \\
\text { semi-market-type } \\
\text { public enterprise }\end{array}$ & Grade $1++$ or higher & Grade $1++$ : less than 80 \\
\hline & Apartment (including studio) & Public institutions & Grade 2 or higher & $\begin{array}{l}\text { Grade 2: } 260 \text { or more } \\
\text { and less than } 320\end{array}$ \\
\hline
\end{tabular}

This certification is a process in which the project promotion department fills out an application for energy efficiency grade and submits it to one of nine certification bodies 
nationwide along with a certain fee. The certification body then issues a certificate and evaluation letter after examination. In particular, the energy consumption for heating, cooling, hot water supply, lighting, and ventilation is calculated by dividing the floor area of each space that requires the corresponding energy; therefore, the business department must submit the design drawing together. Energy consumption uses a mathematical calculation model, and accurate figures are calculated using $\mathrm{ECO}^{2}$, a building energy evaluation program [48]. For a single building, the evaluation is divided into two rounds. In the first preliminary certification, documents with estimated requirements are reviewed before construction. Then, in the second main certification, the final grade is determined after determining whether recalculating the energy requirements for each item is consistent with the on-site verification after construction. The organization undertaking the project can obtain a certificate 50 days after the date of application. Certification fees (excluding residential buildings) range from a minimum of $1600 \mathrm{USD}\left(1000 \mathrm{~m}^{2}\right)$ to a maximum of 16,000 USD $\left(60,000 \mathrm{~m}^{2}\right)$, depending on the exclusive area, excluding common areas, such as stairs, corridors, and parking lots.

As a result of analyzing the NPBC's preliminary review data on these BEE certifications, it is confirmed that $94.8 \%$ of national sports centers fall under the certification target. Among them, $6.9 \%$ had omissions in the plan, even though they were subject to certification. In detail, $89.5 \%$ of the base type and $95.7 \%$ of the living-friendly-type national sports centers were subject to certification, but $10.3 \%$ had errors in the certification plan. According to NPBC's opinion of preliminary review, this was mostly because the project implementation department was not aware of whether mandatory BEE certification was required.

\section{- Zero Energy Building (ZEB) Certification}

In Korea, ZEB is first "passive," which minimizes the building's cooling and heating energy requirements through reinforcement of insulation and airtight performance; second, "active," which minimizes energy consumption through application of high-efficiency facilities and building energy management system (BEMS); and third, it aims for "new and renewable" that produces new and renewable energy through solar power, geothermal heat, and fuel cells [38]. Accordingly, in Korea, ZEB certification gives grades 1 to 5 by calculating the energy self-reliance rate. This rate is the primary energy consumption per unit area divided by primary energy production. In other words, it refers to the ratio of new and renewable energy production to energy consumed by buildings for cooling, heating, hot water supply, lighting, and ventilation. (2) When the energy self-reliance rate is $100 \%$ or more, grade 1 is given; when it is $80 \%$ or more but less than $100 \%$, it is grade 2 ; and when it is $60 \%$ or more but less than $80 \%$, grade 3 is given. Further, $40 \%$ or more but less than $60 \%$ are graded 4 , and $20 \%$ to less than $40 \%$ are graded 5 .

Energy self-sufficiency rate $(\%)=$ Primary energy consumption per unit area $\left(\mathrm{kWh} / \mathrm{m}^{2} \cdot\right.$ year $) /$ Primary
energy production per unit area $\left(\mathrm{kWh} / \mathrm{m}^{2} \cdot\right.$ year $) \times 100$

From 2020, except for apartment houses, public buildings subject to the submission of a building energy code compliance (BECC) with a total floor area of $1000 \mathrm{~m}^{2}$ or more can only be built with mandatory ZEB certification. BECC must be submitted at the time of applying for building permits for new buildings with a total floor area of $500 \mathrm{~m}^{2}$ or more, according to the GBA [49]. The government intends to expand its compulsory target gradually. From 2023, it will be mandatory for public buildings with a total floor area of $500 \mathrm{~m}^{2}$, and from 2025, not only public buildings but also private buildings with a floor area of more than $1000 \mathrm{~m}^{2}$ and apartment houses with 30 or more households will need to comply with this requirement.

For a public building to receive ZEB certification in Korea, the building energy efficiency rating calculated according to the primary energy consumption must be $1++$ or higher and less than $140 \mathrm{kWh} / \mathrm{m}^{2}$, as mentioned above. The energy self-reliance rate should be approximately $20 \%$ or higher. It is also necessary to install a BEMS that measures 
and manages energy consumption in real time or a remote meter reading electronic meter. BEMS is an integrated measurement, control, management, and operating system that monitors energy usage history and provides an optimized energy management plan for the building to maintain a comfortable indoor environment and efficient energy management [50]. Information on renewable energy, hot water supply, gas, heating, cooling power, and lighting power is measured through sensors, and then energy-saving control is activated through software for optimization. BEMS also complies with GBA regulations and is mandatory for public buildings with a total floor area of $10,000 \mathrm{~m}^{2}$ [51].

In Korea's ZEB certification, a certification body approved by the Ministry of Land, Infrastructure, and Transport (MOLIT) receives application documents, including design drawings submitted by public institutions, uses the $\mathrm{ECO}^{2}$ program like BEE certification, and evaluates it in two stages. The certificate is issued within 30 days. The first preliminary certificate is required for the approval of building construction, and the second certificate is required for approval of use. In the past, only the Korea Energy Agency oversaw certification, but recently, MOLIT increased the number of certification agencies to a total of nine to expand the zero-energy buildings. At the time of the introduction of the certification system in 2017, there were only 10 ZEB applications, but in 2020, it surged to 507, and it is expected that the number will exceed 1000 in the near future [37].

As mentioned earlier, since the subject of this ZEB certification is over $1000 \mathrm{~m}^{2}$ of total floor area, almost all national sports centers are currently covered. However, since 2020, when these mandatory regulations were implemented, $56.9 \%$ of all national sports centers have been subject to the ZEB certification plan. Considering the mandatory application period, $82.5 \%$ of plan status was confirmed. In addition, there were missing plans and errors in $8.6 \%$ of the projects. Overall, $5.3 \%$ of the base-type facilities and $82.1 \%$ of the living-friendly facilities were subject to the ZEB certification obligation. As mentioned earlier, this is the result of the certification system becoming mandatory from 2020, while the types of public sports facilities have changed since 2019 . Among them, $12.8 \%$ of the living-friendly facilities did not recognize the compulsory subjects, so they omitted or made the wrong plan.

- Green Standard for Energy and Environmental Design (G-SEED) Certification

The G-SEED evaluates the environmental impact of the entire life cycle of a building, such as location, material selection, construction, maintenance, and disposal, with the goal of sustainable development. Accordingly, the G-SEED gives detailed scores for each item, sums them up, and divides them into grades 1 to 4 according to the score (Table 4). Based on a total of 100 points for non-residential public buildings, 80 points or more for new construction and 75 points or more for remodeling are the best grades. Scores of 65 to 70 or more are graded 2, 55 to 60 or more are graded 3, and 45 to 50 or more grades are graded 4 . According to the government notice, focusing on new non-residential buildings, a total of 45 detailed items are identified in the areas of land use and transportation, energy and environmental pollution, materials and resources, water circulation management, maintenance, ecological environment, and indoor environment; additional points are given for the other 9 items. By examining the detailed evaluation items, it was confirmed that a considerable number of items were checked for each division. In the case of Korea, since the active recognition and implementation of sustainable public buildings has not yet been shown, the mandatory provisions and evaluation items are being approached from various angles. 
Table 4. Green Standard for Energy and Environmental Design (G-SEED) evaluation items (new public buildings) (Source: Green Building Center).

\begin{tabular}{|c|c|c|c|c|}
\hline & Division & & Certification Items & Point \\
\hline \multirow{7}{*}{1} & \multirow{7}{*}{$\begin{array}{l}\text { Land Use and } \\
\text { Transportation }\end{array}$} & 1.1 & The ecological value of the existing land & 2 \\
\hline & & 1.2 & Avoid excessive underground development & 3 \\
\hline & & 1.3 & Minimize the amount of cut soil for earthworks & 2 \\
\hline & & 1.4 & $\begin{array}{l}\text { The feasibility of measures to prevent interference with the right } \\
\text { to sunlight }\end{array}$ & 2 \\
\hline & & 1.5 & Arrangement plan to secure proper sunlight & 1 \\
\hline & & 1.6 & Proximity to public transport & 2 \\
\hline & & 1.7 & Installation of bicycle parking lot & 2 \\
\hline \multirow{8}{*}{2} & \multirow{8}{*}{$\begin{array}{l}\text { Energy and } \\
\text { environmental } \\
\text { pollution }\end{array}$} & 2.1 & Energy performance & 12 \\
\hline & & 2.2 & $\begin{array}{l}\text { Conducting testing, adjustment, and evaluation (TAB), and } \\
\text { commissioning }\end{array}$ & 2 \\
\hline & & 2.3 & Energy monitoring and management support device & 2 \\
\hline & & 2.4 & Lighting energy saving & 4 \\
\hline & & 2.5 & Use of new and renewable energy & 3 \\
\hline & & 2.6 & Application of low-carbon energy source technology & 1 \\
\hline & & 2.7 & Ozone layer protection and global warming reduction & 3 \\
\hline & & 2.8 & Establishment of solar control plan to reduce cooling energy & 2 \\
\hline \multirow{6}{*}{3} & \multirow{6}{*}{$\begin{array}{l}\text { Materials and } \\
\text { resources }\end{array}$} & 3.1 & Use of Environmentally Declared Products (EDPs) & 4 \\
\hline & & 3.2 & Use of low-carbon materials & 2 \\
\hline & & 3.3 & Use of resource recycling materials & 2 \\
\hline & & 3.4 & Use of materials to reduce harmful substances & 2 \\
\hline & & 3.5 & Application rate of green building materials & 4 \\
\hline & & 3.6 & Installation of storage facilities for recyclable resources & 1 \\
\hline \multirow{4}{*}{4} & \multirow{4}{*}{$\begin{array}{l}\text { Water cycle } \\
\text { management }\end{array}$} & 4.1 & Rainwater management & 5 \\
\hline & & 4.2 & Use of rainwater and runoff groundwater & 4 \\
\hline & & 4.3 & Use of water-saving devices & 3 \\
\hline & & 4.4 & Water usage monitoring & 2 \\
\hline \multirow{4}{*}{5} & \multirow{4}{*}{ Maintenance } & 5.1 & Environmental management plan of construction site & 2 \\
\hline & & 5.2 & Provision of operation/maintenance documents and manuals & 2 \\
\hline & & 5.3 & Suppression of dust generation in the playground & 1 \\
\hline & & 5.4 & Provision of G-SEED related information & 3 \\
\hline \multirow{5}{*}{6} & \multirow{5}{*}{$\begin{array}{l}\text { Ecological } \\
\text { environment }\end{array}$} & 6.1 & Creation of linked greenery axis & 2 \\
\hline & & 6.2 & Natural Ground Greenery Ratio & 4 \\
\hline & & 6.3 & Ecological area ratio & 6 \\
\hline & & 6.4 & Biotope composition & 4 \\
\hline & & 6.5 & Creation of ecological learning center & 1 \\
\hline
\end{tabular}


Table 4. Cont.

\begin{tabular}{|c|c|c|c|c|}
\hline & Division & & Certification Items & Point \\
\hline \multirow{10}{*}{7} & \multirow{10}{*}{$\begin{array}{l}\text { Indoor } \\
\text { environment }\end{array}$} & 7.1 & Application of products with low emission of indoor air pollutants & 3 \\
\hline & & 7.2 & Securing natural ventilation performance & 2 \\
\hline & & 7.3 & Design of outdoor air supply and exhaust ports & 2 \\
\hline & & 7.4 & $\mathrm{CO}_{2}$ monitoring system operation and ventilation rate evaluation & 2 \\
\hline & & 7.5 & Thermostat installation level & 2 \\
\hline & & 7.6 & Adoption of comfortable indoor environment control method & 2 \\
\hline & & 7.7 & Sound insulation performance of boundary walls between rooms & 2 \\
\hline & & 7.8 & Indoor and outdoor noise level for traffic noise (road, rail) & 2 \\
\hline & & 7.9 & Sunshade installation to control direct sunlight and reduce glare & 2 \\
\hline & & 7.10 & Creation of a dedicated rest area & 1 \\
\hline \multirow{10}{*}{ Addition } & \multirow{10}{*}{$\begin{array}{l}\text { Innovative } \\
\text { design }\end{array}$} & 1 & $\begin{array}{l}\text { Land use and transportation: installation of alternative } \\
\text { transportation-related facilities }\end{array}$ & 1 \\
\hline & & 2 & Energy and environmental pollution: Zero Energy Building & 3 \\
\hline & & 3 & Materials and resources: conducting building life cycle evaluation & 2 \\
\hline & & & Reuse of major structural parts of existing buildings & 5 \\
\hline & & 4 & $\begin{array}{l}\text { Water circulation management: reuse of gray water and sewage } \\
\text { and wastewater treatment water }\end{array}$ & 1 \\
\hline & & 5 & $\begin{array}{l}\text { Maintenance: environmental management of green construction } \\
\text { sites }\end{array}$ & 1 \\
\hline & & 6 & Ecological environment: topsoil recycling rate & 1 \\
\hline & & 7 & Indoor environment: securing natural light performance & 1 \\
\hline & & & Design participation by green building certification experts & 1 \\
\hline & & & $\begin{array}{c}\text { Innovative green building planning and design: evaluation } \\
\text { through deliberation }\end{array}$ & 3 \\
\hline
\end{tabular}

G-SEED is applied to not only new constructions but also existing and remodeled buildings. In particular, from 2013, public buildings with a total floor area of $3000 \mathrm{~m}^{2}$ or more ordered by public institutions must obtain this certification. Since this certification is a comprehensive evaluation of the environmental performance of a building, the validity period is set for five years.

G-SEED is operated by the Korea Construction Research Institute. It accepts applications from 10 certification organizations across the country, and is evaluated by the Certification Deliberation Committee, and then given a certification grade. This certification does not evaluate only the results derived from accurate formulas such as BEE or ZEB, so the committee directly reviews related materials. The applicant organization submits a self-evaluation report and basic drawings (plan, elevation view), which must receive the first preliminary certification in the design phase and the secondary certification in the use approval phase.

As a result of analyzing the results of this G-SEED certification plan for national sports centers, $81 \%$ of the total fell under the certification target, and there were omissions or errors in the certification plan of $6.9 \%$. Among the detailed types, $78.9 \%$ of the base-type facilities and $82.1 \%$ of the living-friendly facilities were subject to the G-SEED obligation. As with the ZEB certification results, there were $10.3 \%$ omissions and errors only in livingfriendly facilities. 


\section{- $\quad$ Synthesis}

This study examines the energy efficiency certifications that must be confirmed in the planning process when creating public buildings in Korea and analyzes the current state of the plan, focusing on public sports facilities. Energy efficiency certifications applicable to these facilities are BEE, ZEB, and G-SEED according to the GBA, which is mandatory for buildings over $3000 \mathrm{~m}^{2}, 1000 \mathrm{~m}^{2}$, and $3000 \mathrm{~m}^{2}$ based on the total floor area. A summary of the plans and omissions for the three certifications mandatory for public sports facilities is as follows (Figure 1). Among public sports facilities, $94.8 \%$ of national sports facilities created with the NSPF were subject to BEE, 56.9\% ZEB, and 81\% G-SEED. In particular, there were omissions or errors in $10.3 \%, 12.8 \%$, and $10.3 \%$, respectively, in the plan for livingfriendly-type facilities created recently. In the case of the ZEB certification plan, a relatively low rate is confirmed because certification is not compulsory before the establishment of a living-friendly-type facility. However, even considering this, omissions or errors occurred in approximately $12.8 \%$ of the plans.

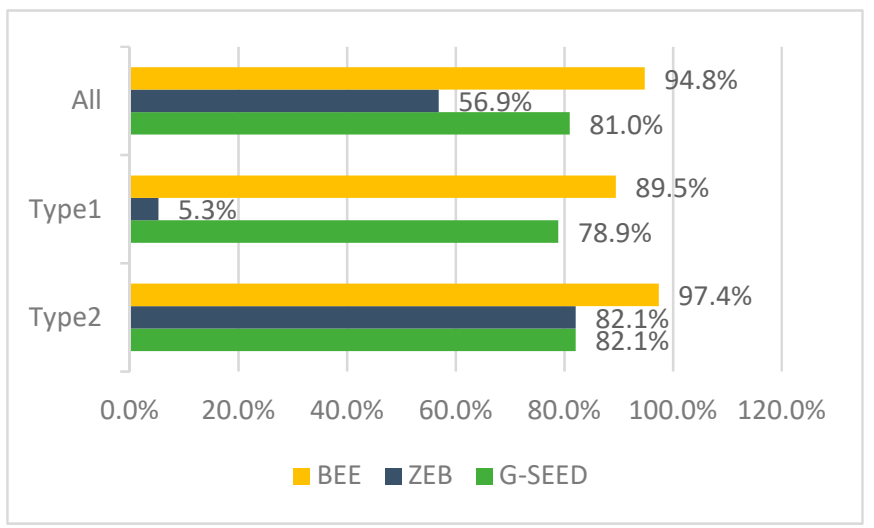

(a)

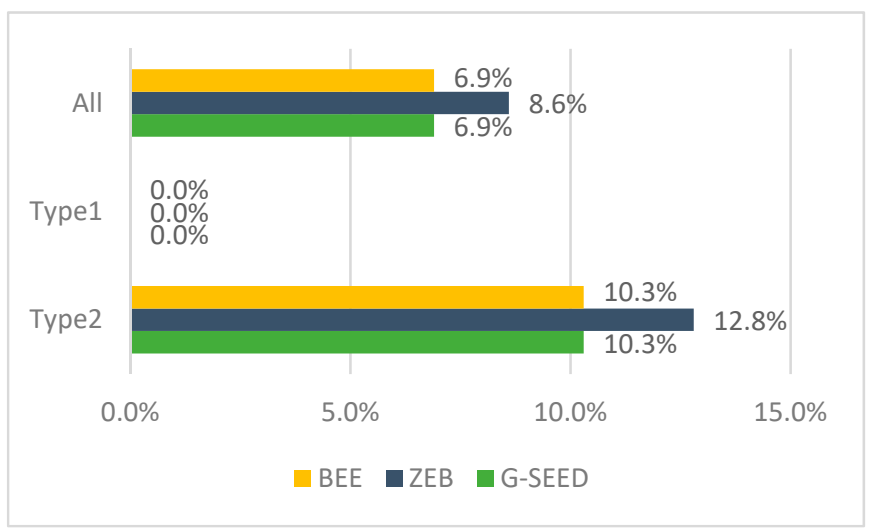

(b)

Figure 1. Status of certification plans by type of national sports centers: (a) Plan status; (b) missing and error status (Type1: Base-type facility; Type2: Life-friendly-type facility)

\section{Discussion}

In this study, I checked the current status of plans for energy efficiency certifications that should be mandatory for sports facilities among public buildings, and it is urgent to activate the plan of certifications. Improvement for this is discussed in five aspects as follows.

First, raising awareness of the need for the plan should be the first priority to prevent omissions. In addition, public relations and support projects at the government level need to be expanded. In particular, ZEB will be mandatory, from 2023, for public buildings of $500 \mathrm{~m}^{2}$ or larger. Hence, almost all public buildings will be covered. Therefore, if a business department wants certification consulting, it provides free support as part of its preparation. In Korea, there is rarely a separate department that promotes public architecture, and in most cases, the person in charge of each department is not concerned with the major architectural plans and executes the project. Therefore, public relations and support projects, including education, should be prioritized in such administrative structures.

In addition, the mandatory application of the energy efficiency certification system will be expanded, especially for public buildings. Hence, the method of evaluating "everything" related to energy saving needs to be discouraged. Evidently, all aspects of energy efficiency need to be considered in major government projects. However, in the process of creating small and medium-sized buildings in local governments, a gradual approach, such as which aspects to plan first, will be a way to increase the effectiveness of the system. For this purpose, detailed categories of evaluation and incentives should be prepared. 
Above all, to increase the voluntary performance of business departments on the certification plan for the sustainability of public buildings, it is effective to systematically strengthen the incentives for each application. Currently, in the case of BEE certification, when receiving grades $1+$ and 1 and G-SEED certification, the acquisition tax and property tax of new buildings are partially exempted, and standards, such as floor area ratio and height of new buildings, are relaxed. The relaxation of building standards for new buildings is also applied at the time of ZEB certification, but there is a difference in the relaxation rate from grades 1 to 5 (Table 5). In particular, since the rate of omissions and errors in the ZEB plan is relatively high for national sports centers, it is necessary to consider the expansion of incentives for this.

Table 5. Summary of incentives for relaxation of building standards by building efficiency certification.

\begin{tabular}{cccccc}
\hline Division & \multicolumn{3}{c}{ Certification Level } \\
\hline BEE & $1+$ & $1+$ & 1 & 1 \\
\hline G-SEED & very best & great & very best & great \\
\hline Incentive & $9 \%$ & $6 \%$ & $6 \%$ & 4 & $3 \%$ \\
\hline ZEB & 1 & 2 & 3 & & $12 \%$ \\
\hline Incentive & $15 \%$ & $14 \%$ & $14 \%$ & & $11 \%$ \\
\hline
\end{tabular}

The business department must ensure that there are no omissions or errors in the certification plan so that future implementation is not disrupted. Above all, by understanding incentives, it is necessary to contract with an architect after considering the budget and the size of the structure that can be planned. In particular, a national sports center is often planned in a complex way, including swimming pools and gyms, as well as resident public facilities, such as libraries. Therefore, unnecessary budget and period losses may occur in the future because there are many aspects to be considered in the design process. Above all, since the relaxation of building standards among incentives must be planned and applied before project approval is granted through public building deliberations, it must be clearly judged and provided as a guideline before the architect begins working on the basic design.

This energy efficiency plan is primarily reviewed through a preliminary review by NPBC in the public building construction process. Business departments can select experts, such as architects, through public building deliberation after supplementing according to the opinions of the NBPC. Therefore, it is necessary to review the energy efficiency plan more closely and present opinions in the preliminary review and public building deliberation. Above all, the preliminary review is the only process that objectively confirms the plan and provides important opinions on reducing unnecessary changes in the subsequent process. Currently, NPBC mainly judges only the presence or absence of a plan through a preliminary review and provides opinions only on omissions. However, information and opinions on the certification system procedure and budgeting, such as fees, and the possibility of changes, such as the size due to incentives, should be provided to business departments that lack general knowledge and understanding of building construction.

\section{Conclusions}

This study confirms the energy efficiency certification system for the sustainability of buildings and national sports centers, which have been expanding recently in Korea and urgently need an efficiency plan due to high energy consumption, and then analyzes the actual plan status and discusses operational improvements. BEE certification, ZEB certification, and G-SEED certification are mainly considered in the planning process of a national sports center, which is a public sports facility. Whether these certifications are mandatory depends on the total floor area of the building. As a result of analyzing the plan status, when considering the timing of certification, more than $80 \%$ of all facilities were subject to mandatory requirements, but omissions or errors in certification were confirmed during planning in about $10 \%$ of each of them. 
In this study, while preparing for the gradually expanding mandatory regulations, the government's role and system complementation for revitalizing plan, the role of business departments, and the function of the preliminary review, a review procedure for these plans, were discussed. Under the same conditions as in Korea, where most business departments are composed of administrative-oriented personnel rather than architecture specialists, it is important to expand publicity and support from the government, differential application of evaluation items is required, and incentives must be strengthened.

While strategies for energy efficiency in buildings are being sought around the world, this study is meaningful in that it confirms how much energy efficiency plans are being implemented in what kind of certification system, centering on public buildings in Korea, and suggests improvement points at the institutional level. The matters discussed in this study need to be institutionalized as detailed guidelines.

However, this study has limitations in that it does not draw improvement items for energy efficiency in the technical aspects of public sports facilities. In the next 2-3 years, the actual results of buildings should be comprehensively tracked and analyzed. In addition, in Korea, the ZEB certification grade is given without much consideration of the specificity of each type in relation to equipment or materials. In particular, as mentioned in Section 2 , although architectural space design is closely related to the effects that occur in actual use of buildings in relation to thermal performance and air quality, it is still treated as an additional dimension. This issue should be discussed in earnest in the near future in relation to energy evaluation.

Funding: This research received no external funding.

Institutional Review Board Statement: Not applicable.

Informed Consent Statement: Not applicable.

Data Availability Statement: Data sharing is not applicable to this article.

Acknowledgments: This study includes the results of the analysis based on the preliminary review data of the National Public Building Center with regards to the "Public Architecture from the User's Perspective: National Sports Facility" report (published in December 2021).

Conflicts of Interest: The author declares no conflict of interest. The funders had no role in writing the manuscript.

\section{References}

1. International Energy Agency. World Energy Outlook; IEA Publications: Paris, France, 2017; Available online: https://www.iea. org/media/weowebsite/2017/Chap1_WEO2017.pdf (accessed on 2 November 2021).

2. International Energy Agency. Available online: https://www.iea.org (accessed on 2 November 2021).

3. Jefferson, D.; Paige, F.; Agee, P.; Jackson, F. User Experience of Green Building Certification Resources: EarthCraft Multifamily. Sustainability 2021, 13, 7871. [CrossRef]

4. Asere, L.; Blumberga, A. Government and Municipality Owned Building Energy Efficiency System Dynamics Modelling. Energy Procedia 2015, 72, 180-187. [CrossRef]

5. Zhang, Y.; Wang, Y. Barriers' and policies' analysis of China's building energy efficiency. Energy Policy 2013, 62, 768-773. [CrossRef]

6. International Energy Agency. Korea 2020 Energy Policy Review; IEA Publications: Paris, France, 2020.

7. Park, D.J.; Yu, K.H.; Yoon, Y.S.; Kim, K.H.; Kim, S.S. Analysis of a Building Energy Efficiency Certification System in Korea. Sustainability 2015, 7, 16086-16107. [CrossRef]

8. Korean Law Information Center. Available online: https: / / www.law.go.kr/LSW/eng/engMain.do?eventGubun=060124 (accessed on 2 November 2021).

9. Lim, H.; Eun, J. Exploring Perceptions of Sustainable Development in South Korea: An Approach Based on Advocacy Coalition Framework's Belief System. J. Open Innov. Technol. Mark. Complex. 2018, 4, 54. [CrossRef]

10. Mathews, J.A. Green growth strategies: Korean initiatives. Futures 2012, 44, 761-769. [CrossRef]

11. Weerasinghe, A.S.; Ramachandra, T. Economic sustainability of green buildings: A comparative analysis of green vs non-green. Built Environ. Proj. Asset Manag. 2018, 8, 528-543. [CrossRef]

12. Ries, R.; Bilec, M.M.; Gokhan, N.M.; Needy, K.L. The Economic Benefits of Green Buildings: A Comprehensive Case Study. Eng. Econ. 2006, 51, 259-295. [CrossRef] 
13. Kim, J.T.; Yu, C.W.F. Sustainable development and requirements for energy efficiency in buildings: The Korean perspectives. Indoor Built Environ. 2018, 27, 734-751. [CrossRef]

14. Seo, M. Accommodation of Western Modernism in Korean Architecture: A Case Study of Dong-jin Park (1899-1981). J. Asian Archit. Build. Eng. 2017, 16, 263-270. [CrossRef]

15. Baek, S.G.; Kwon, H.A. Participatory Planning through Flexible Approach: Public Community Facilities in Seoul's Urban Regeneration Project. Sustainability 2020, 12, 10435. [CrossRef]

16. Korea Policy Briefing. Available online: https:/ /Korea.kr (accessed on 2 November 2021).

17. National Public Building Center. Preliminary Review of Public Building Projects: 2019 Annual Report; Architecture \& Urban Research Institute: Sejong, Korea, 2019.

18. National Public Building Center. Public Building Statistics; Architecture \& Urban Research Institute: Sejong, Korea, 2020.

19. Hughes, N. Towards improving the relevance of scenarios for public policy questions: A proposed methodological framework for policy relevant low carbon scenarios. Technol. Forecast. Soc. Chang. 2013, 80, 687-698. [CrossRef]

20. Stagl, S. Multicriteria evaluation and public participation: The case of UK energy policy. Land Use Policy 2006, 23, 53-62. [CrossRef]

21. MacArthur, J.L. Challenging public engagement: Participation, deliberation and power in renewable energy policy. J. Environ. Stud. Sci. 2016, 6, 631-640. [CrossRef]

22. Cai, W.G.; Wu, Y.; Zhong, Y.; Ren, H. China building energy consumption: Situation, challenges and corresponding measures. Energy Policy 2009, 37, 2054-2059. [CrossRef]

23. Park, K.; Kim, Y.; Kim, S.; Kim, K.; Lee, W.; Park, H. Building Energy Management System based on Smart Grid. In Proceedings of the 2011 IEEE 33rd International Telecommunications Energy Conference (INTELEC), Amsterdam, The Netherlands, 9-13 October 2011; IEEE: New York, NY, USA; p. 12471351. [CrossRef]

24. Kim, Y.; Yu, K.-H. Study on the Certification Policy of Zero-Energy Buildings in Korea. Sustainability 2020, 12, 5172. [CrossRef]

25. Lee, J.; Shepley, M.M.; Choi, J. Exploring the effects of a building retrofit to improve energy performance and sustainability: A case study of Korean public buildings. J. Build. Eng. 2019, 25, 100822. [CrossRef]

26. Lee, H.S.; Kim, S.H.; Kim, J.; Kim, J.T.; Jang, C.Y. Analysis of the Building Energy Efficiency Rating Certified for Public Office Buildings. Korea Inst. Ecol. Archit. Environ. 2015, 15, 75-82. [CrossRef]

27. Kim, H.; Park, W. A Study of the Energy Efficiency Management in Green Standard for Energy and Environmental Design (G-SEED)-Certified Apartments in South Korea. Sustainability 2018, 10, 3402. [CrossRef]

28. Kim, M. A Study on the Development and Implementation Plan of the National Sports Center that Is Closely Related to Life; Ministry of Culture, Sports and Tourism: Sejong, Korea, 2018.

29. Korea Sports Promotion Foundation. Available online: https://www.kspo.or.kr/english/main/main.do (accessed on 2 November 2021).

30. Ministry of Culture, Sports and Tourism. Available online: https:/ /www.mcst.go.kr (accessed on 2 November 2021).

31. National Public Building Center. Available online: https://www.npbc.or.kr (accessed on 2 November 2021).

32. Yezioro, A.; Capeluto, I.G. Energy Rating of Buildings to Promote Energy-Conscious Design in Israel. Buildings 2021, 11, 59. [CrossRef]

33. Khan, M.A.; Wang, C.C.; Lee, C.L. A Framework for Developing Green Building Rating Tools Based on Pakistan's Local Context. Buildings 2021, 11, 202. [CrossRef]

34. Jeong, J.; Hong, T.; Ji, C.; Kim, J.; Lee, M.; Jeong, K.; Koo, C. Development of a prediction model for the cost saving potentials in implementing the building energy efficiency rating certification. Appl. Energy 2017, 189, 257-270. [CrossRef]

35. Korea Research Institute of Eco-Environmental Architecture. Available online: https:/ / www.kriea.re.kr/eng_index.php (accessed on 2 November 2021).

36. Certification Information Center. Available online: https://www.certinfo.kr/index.do (accessed on 2 November 2021).

37. Ministry of Land, Infrastructure and Transport. Available online: https://www.molit.go.kr/USR/NEWS/m_71/dtl.jsp?id=95085603 (accessed on 2 November 2021).

38. Zero Energy Building. Available online: https:/ / zeb.energy.or.kr (accessed on 2 November 2021).

39. Topriska, E.; Kolokotroni, M.; Melandri, D.; McGuiness, S.; Ceclan, A.; Christoforidis, G.C.; Fazio, V.; Hadjipanayi, M.; Hendrick, P.; Kacarska, M.; et al. The Social, Educational, and Market Scenario for nZEB in Europe. Buildings 2018, 8, 51. [CrossRef]

40. Teni, M.; Culo, K.; Krstic, H. Renovation of Public Buildings towards nZEB: A Case Study of a Nursing Home. Buildings 2019, 9, 153. [CrossRef]

41. Garcia, J.F.; Kranzl, L. Ambition Levels of Nearly Zero Energy Buildings (nZEB) Definitions: An Approach for Cross-Country Comparison. Buildings 2018, 8, 143. [CrossRef]

42. Taherahmadi, J.; Noorollahi, Y.; Panahi, M. Toward comprehensive zero energy building definitions: A literature review and recommendations. Int. J. Sustain. Energy 2020, 40, 120-148. [CrossRef]

43. D'Agostino, D.; Mazzarella, L. What is a Nearly zero energy building? Overview, implementation and comparison of definitions. J. Build. Eng. 2019, 21, 200-212. [CrossRef]

44. Hernandez, P.; Kenny, P. From net energy to zero energy buildings: Defining life cycle zero energy buildings (LC-ZEB). Energy Build. 2010, 42, 815-821. [CrossRef]

45. Omrany, H.; Seobarto, V.; Zuo, J.; Sharifi, E.; Chang, R. What leads to variations in the results of life-cycle energy assessment? An evidence-based framework for residential buildings. Energy Built Environ. 2021, 2, 392-405. [CrossRef] 
46. Shao, Y.; Hao, S.; Luo, Y.; Xing, J.; Liu, Z. Practices on Sustainable Design for College Sports Building: Take Zhengzhou Tourism College Stadium as an Example. Appl. Mech. Mater. 2012, 174, 3130-3133. [CrossRef]

47. Manni, M.; Coccia, V.; Nicolini, A.; Marseglia, G.; Petrozzi, A. Towards Zero Energy Stadiums: The Case Study of the Dacia Arena in Udine, Italy. Energies 2018, 11, 2396. [CrossRef]

48. Building Energy Efficiency Grade Certification System. Available online: https://beec.energy.or.kr/BC/BC04/BC04_05_002.do? no=6 (accessed on 2 November 2021).

49. Korea Energy Agency. Available online: http://www.kemco.or.kr/web/kem_home_new/ener_efficiency/building_08.asp (accessed on 2 November 2021).

50. Korea Energy Management System Industry Association. Available online: https://www.bems.or.kr/bbs/content.php?co_id= eng_ceo (accessed on 2 November 2021).

51. Korea Energy Agency. Available online: http://www.kemco.or.kr/web/kem_home_new/ener_efficiency/building_09.asp (accessed on 2 November 2021). 